\title{
Principal-Agent in Implementing Village funds in Linggo Village, Kejayan District, Pasuruan Regency
}

\author{
Aminullah ${ }^{\mathrm{a}}$ * \\ ${ }^{a}$ Yudharta University, Pasuruan, East Java, Indonesia
}

\section{ARTICLE INFORMATION}

\section{Article history:}

Data submission : 10 June 2020

$1^{\text {st }}$ revision: 10 August 2020

Accepted: 16 November 2021

Available online: 10 December 2021

Keywords: principal-agent, public policy implementation, village funds

\section{ABSTRACT}

The village fund is one of the many policy programs carried out by the government sourced from the state budget (APBN) which is allocated directly to the village. But in the implementation of the village fund, there are still problems so that in general the village fund is still not effective. This study analyzes the role of actors in the implementation of village funds from the perspective of the principal-agent whose locus is in Linggo village, Kejayan district, pasuruan regency. The focus in this study is the role of principal and agent in the stages of planning, implementation, and reporting of the village fund by measuring the effectiveness of implementation through the principles for cultivating effective implementation practice. Novelty of this research is to see the effectiveness of the implementation of the village fund from the perspective of the relationship of the principal agent. This study aims to create a model of the effectiveness of the village fund policy implementation in linggo village, kejayan district. The results showed that the relationship between the principal and agent must increase oversight so that the policy objectives can be achieved.

2021 FIA UB. All rights reserved.

\section{Introduction}

The enactment of Law No. 6 of 2014 concerning villages, provides new enthusiasm for the people who so far have sometimes only acted as spectators in regional development. The community is given the authority to recognize the right of origin (recognition), the establishment of local scale authority and local decision making for the benefit of the village community (subsidiarity), diversity, togetherness, cooperation, kinship, deliberation, democracy, independence, participation, equality, empowerment, and continuity.

In its implementation, Law No. 6 of 2014 there are still weaknesses, especially among others related to the position of indigenous and tribal peoples, democratization, diversity, community participation, and progress and equitable development that is not yet optimal so that there are still weaknesses and shortcomings that will later become signals that will cause disparities between regions, poverty, and sociocultural problems, in the end, can disrupt the integrity of the unitary state of the Republic of Indonesia.

To solve the problems as noted above, of course, financial support or adequate sources of funding are needed, so that village authority can be fulfilled under the characteristics of the village itself. Therefore, with the enactment of Law Number 6 of 2014 concerning villages, it gives a positive signal in the distribution of development. The source of financing as intended is very clear to the Village, namely in Articles 71 to 75 of Law Number 6 of 2014 concerning villages regulating sources of financing in the village, sources of income in the Village such as Original Village Revenues (PADes), Allocation from the APBN, revenue sharing from regency / city tax and retribution, financial assistance from the province and regency / city, grants or third party donations that are not binding as well as other village income that is legal.

The village revenues mentioned above are some details that are the obligation of the government to be transferred from the Regional General Cash Account (RKUD) to the Village Cash Account, namely: first, the Village fund Allocation (ADD), is the allocation of funds to the village with the calculation of the Balanced Fund received by the Regency / City by $10 \%$ after deducting the Special Allocation Fund (DAK). The legal basis for the allocation of the balancing fund to the village by the mandate of Law Number 6 of 2014 Article 72 paragraph (4), if this is not carried out then strict sanctions are stated in article 72 paragraph (6), 
whereby the government can postpone and/or deduction of the allocation of the balancing fund after deducting the special allocation fund.

Second, the village fund is a fund sourced from the state revenue and expenditure budget intended for villages that are transferred through the regency/city regional revenue and expenditure budget and are used to finance governance, development implementation, community development, and community empowerment. Provisions governing the village fund are Government Regulation Number 60 of 2014 concerning village funds sourced from the State Budget for the implementation of Article 72 paragraph (1) letter b and paragraph (2) of Law Number 6 of 2014 concerning villages.

The village fund allocation is calculated based on the number of villages and allocated by taking into account the population, poverty rate, area size, and geographical difficulty level. In Government Regulation Number 60 the Year 2014 and the Amendment Government Regulation Number 22 the Year 2015 in Article 11 paragraph (2) Village funds are allocated by calculating the basic allocation and allocation calculated by considering the population, area, poverty rate, and geographical difficulty level.

Based on the amount of the budget set by the central government in the 2015 revenue and expenditure budget plan, the village is given the authority to regulate and manage its authority by the needs and priorities of the village. That means the village fund will be used to fund the entire village authority by the needs and priorities of the village fund. Since the village fund is sourced from central expenditure (APBN), to optimize the use of village funds, the village government is given the authority to determine the priority of using village funds to support village development programs and empowering village communities.

The prioritization of the use of these funds remains in line with the authority that is the responsibility of the village. Based on Government Regulation No. 60 of 2014, Village funds are funds sourced from the State Revenue and Expenditure Budget allocated for villages that are transferred through the Regency / City Regional Revenue and Expenditure Budget (APBD) and are used to finance government administration, development implementation, an article development community, and community empowerment. Government Regulation Number 60 the Year 2014 was then revised again through Government Regulation Number 22 the Year 2015. The substance changed in Government Regulation Number 60 the Year 2014 to Government Regulation Number 22 the Year 2015 is the formula for allocating or distributing Village funds from the Central Government to Regencies / Cities and from the Regency / City to the Village.

Village funds are funds allocated to the village government that are used to improve community service facilities, institutions, and village infrastructure that are needed and prioritized by the community, whose utilization and administration of management are carried out and accounted for by the village head. The purpose of granting village funds is as a stimulant aid or stimulant fund to encourage in funding the village government program which is supported by the participation of community mutual assistance in carrying out government activities and community empowerment.

Village funds that are budgeted by the central government nationally in the national budget every year must be managed in an orderly, obedient to the provisions of the legislation, efficient, economical, effective, transparent, and responsible by taking into account a sense of justice and propriety and prioritizing the interests and needs of the local community. Related to village funds sourced from the State Budget (APBN), in line with the implementation of regional autonomy that further implications of the central government as the executor of the government of the Unitary Republic of Indonesia are obliged to give trust to the regional government further to the village government as autonomous to manage budget activities under their main tasks and functions, priority use of the budget, with the hope that the creation of community independence by continuing to preserve the values of cooperation in the community.

The facts above prove that the implementation of the village fund has not been effective as expected. Synergy is needed from all elements of government ranging from the central government to the village government to achieve the objectives of the village fund as the central government formulation in this connection to the Ministry of Villages, Regional Development, and Transmigration.

Implementation will run effectively if the performance indicators set by the Government have been achieved. Indicators of the success of the implementation of village funds include the program planned in the RAPBDesa by the outline of the village fund policy that has been set, the implementation strategy in the field by environmental conditions while still adhering to the rules and legislation in force.

Pasuruan regency is one of the regencies in East Java, East Java Province is one of the Provinces that receives the most village funding, amounting to 2.21 Trillion. Pasuruan regency is one of the regencies that has a large number of villages, namely 341 Villages. Concerning village funds, Pasuruan regency received a village fund of Rp. 215. 692. 362 billion. The Number of villages in Pasuruan Regency 341 villages spread over 24 Districts. More detailed village funds received by each village were recorded at Rp. 565,640 million (DPJK data of the Ministry of Finance FY. 2016). In addition to village funds, villages in Pasuruan Regency also receive substantial funds, namely the Village fund Allocation (ADD) sourced from the District APBD, as well as funds for the sharing of taxes and levies.

On the other hand, based on observations made by researchers, there were several problems related to the implementation of village funds, in terms of village fund management that was not yet on target, in the sense that the management process was not by what had been formulated by the principal, as happened in Linggo village, Kejayan District Pasuruan, the use of village funds is not by the Principal's formulation, in this case, the central government. The priority of the use of village funds carried out in Linggo village, Kejayan Subdistrict, Pasuruan Regency, appears that village spending priorities are used for needs such as the renovation of 
the village Head's office, facilities, and infrastructure for places of worship such as the construction of bathrooms, paving yard for worship places. This problem arises because agents in this case the village administration in the period of the replacement of the new village head who is still adapting to village administration and not yet maximizing knowledge of village fund management. This change of village head occurred after the disbursement of village funds in phase I, so this became a problem for the village administration. Another incident also occurred in Linggo village, Kejayan subdistrict, Pasuruan regency, as a result of initial observations the researchers saw the use of village funds were used in revamping the construction of the village office, repairing the floor, fence, interior renovation of the village office.

Another fact related to the management of village funds, which is the suboptimal use of village funds that leads to community empowerment. The village government in this case the agency is still preoccupied with activities that only focus on village routine activities. In connection with this problem, researchers through temporary observations have seen that in Wonorejo and Linggo villages, it has not been optimal in paying attention to activities related to community empowerment activities.

The use of village funds that are not optimal indicates that the implementing resources of policies that are not capable, communication from the Principal and agents that are not harmonious with the village fund policies, disposition, and bureaucratic structure of the Principal and agents are still not optimal in their implementation.

From the whole facts above it proves that the implementation of the village fund policy in Pasuruan Regency has not been effective in its implementation, therefore the writer is interested in conducting this research, the implementation must be done properly and correctly by the formulation set by the Principal in this case, the Central Government through Ministry of Villages, Disadvantaged Regions and Transmigration. This requires a harmonious relationship between the Principal and the agent in terms of village fund management.

\section{Theory}

\subsection{Policy implementation}

The problem of implementation is a crucial stage in the policy process (Standford \& Moulton, 2014). This is by Edwards III's statement that without effective implementation the decision of the policymaker will not be successfully implemented. Policy implementation is an activity that is seen after issuing valid directives from a policy that includes efforts to manage inputs to produce outputs or outcomes for the community.

Implementation is a general process of administrative action that can be examined at a particular program level. They added that the implementation process will only start when the goals and objectives have been set, the activity program has been arranged and the funds are ready and have been channeled to achieve the goals.

Policy implementation connects the policy objectives and their realization with the results of government activities. The task of implementation is to build a network that enables public policy objectives to be realized through the activities of government agencies involving various stakeholders (policy stakeholders).

The effectiveness of implementation as stated by Sanford and Moulton (2014) is as follows: "to carry out programs successfully, it is essential for implementers to have a clear sense of the results desired to help shape implementation activities. But often it is difficult to narrow down the possible options. One can easily ask, "Desired results according to whom, and for what purpose?" However, just because desired results are often subjective it does not imply that anything goes".

To carry out the program successfully, it is very important for the Implementer that the clarity of the desired results is a reference for the implementor regarding the form of activities to be carried out. However, there are often difficulties in narrowing down the possibility of raising options. For example, the question arises: According to who do you want the results, and for what purposes? However, just because the desired results are often subjective, it does not mean that anything can happen.

Referring to the opinion of Sanford and Moulton above, if it is related to the perspective of the principalagent, it is very clear that the desired goal of implementing village funds is the formulation of goals that have been set by the principal, in this case, the relevant ministries, and the goal is very clear to develop the village to be more advanced, prosperous and mandiri. Following the broad outline of the central government's goal of developing indonesia from the periphery.

Sanford and Moulton (2014) suggest that the issues of policy implementation are defined in detail as follows: "Implementation issues appear in less-dramatic gestures than the passage of major health care reform. any program or idea for an initiative is shared, practical questions about implementation often follow right behind. How do we take these mandates and make real in our state? How do we pull together the right people to respond to the large foundation's request for a proposal? When a grant proposal is funded, how do we empower the program managers to develop procedures and training for staff? While we both recognize the urgency of these questions, we also believe that it is important to understand each question in its larger, systemic context. The first step in developing this ability is to internalize helpful lessons from social science that provide new ideas and consistent language for your analysis.

Implementation issues arise in movements that are less dramatic than compared to the core of health care reform. every new program or idea for a joint initiative, practical questions about implementation follow right behind it. The first step in developing this ability is to internalize social science which provides new ideas and language skills as a tool of implementation analysis.

Implementation of policies and programs has a way of saying about the analysis of the system's complexity of implementation, so it is likely that the implementation of policies and programs can help produce the desired results. However, implementation also depends on implementers who have to recognize their essential role in this system. This requires professionalism and hard work to develop the social analysis skills needed to understand interference in complex systems. This 
requires courage to acknowledge ambiguity and take action, especially seizing employment opportunities at several levels of the system.

Standford and Moulton (2014) further said that "Effective implementation requires people with many more diverse skills and orientations. As we will see, there are many different positions within the implementation system, many distinct actors playing different roles. Knowledge of the policy or program area and the target population attempting to be reached is essential. But so are tactical and managerial skills that allow one regardless of official position to mobilize resources and make a change". That effective implementation requires resources with lots of diverse skills and orientation. As we will see, there are many different positions in the implementation system, many different actors with different roles. Knowledge of regional policies or programs and target populations is very important to achieve. But tactical and managerial skills also allow one to break away from official positions to mobilize resources and make changes.

The above expression implies the importance of implementing resources, visionary actors who have diverse skills and very important role so that the effectiveness of implementation can be realized. So with human resources who have the skills and visionary will be able to provide changes in implementing a policy. Standford and Moulton (2014) further explain three principles of cultivating effective implementation practice: (1) Know the context where you can affect change: the participants and resources, sources of power, and cultural values; (2) Unpack the core program (viable options, logic of change, and coordination), and identify changes to bring about public value results; and (3) Confront the technical and adaptive challenges necessary to create change, applying analytical inquiry and social skill.

From the table above, it can be understood that the principles of fostering the practice of effective implementation can be seen in 3 ways, namely: first, knowing the context in which we can influence change: participants, and resources, sources of power, and cultural values. Second, dismantling to understand the core program (appropriate choices, the logic of change, and coordination), and identifying changes to achieve public value results. Third, face technical and adaptive challenges to what is needed to create change, apply analytical inquiry and social skills.

Thus the principles that must be applied in the effectiveness of implementation become a necessity because in the implementation of the policy will never be separated from discussing the context of the policy, besides that the program chosen as an action in the implementation must be able to influence change, and face technical challenges because in the hands it will encounter technical things that are sometimes not analyzed, this must be resolved immediately because if left unchecked there will be obstacles in achieving the effectiveness of certain policies.

\subsection{Principal-Agent Theory}

Public organizations, bureaucracies, institutions, and even companies are increasingly facing demands for transparency and efficiency. This has become a macro demand made by the general public/public, especially to politicians. We often hear this from public institutions and even from parliament. How, then, can public organization managers meet the challenges of two major challenges namely: First, transparency based on the rule of law (public administration perspective); Second, efficiency in implementing policies through outputs and outcomes (policy perspectives).

The above challenges must be able to be answered by public administrators, bureaucrats, or government officials in running the wheels of government, for the realization of transparent public services and the effective implementation of policies that have been made.

Smith and Larimer (2009) suggest that to overcome the above problems, of course, between superiors and subordinates must enter into negotiations in carrying out contracts to commit hard work to improve the quality of maximum results.

The principal agent's perspective was started and developed since the 1970s to understand the interactions between company owners and employees in private sector organizations (wijaya \& danar, 2014). However, lately, this approach has begun to develop for use in the public sector to understand the problems of public sector organizations, especially bureaucrats. The key point of the principal agency theory is that the relationship between principals and agents must be reflected in an efficient and effective form of organization. Smith and larimer (2009) said that the principal-agent framework appears initially in the analysis of the private sector where human interactions are more complex than simple games learned from classical game theory.

The implication of agency theory if synergized with the public policy can be seen in the process of implementing public policy, in this case, it can be seen from three perspectives, namely: 1) the relationship between the principal and the agent, 2) the relationship between the principal and the community, 3) the relationship of the agent and the community.

The linkage that occurs as referred to above is how the communication occurs between the actors both to the principal, agents, and the community as the object of the policy. Principals and agents in the process of implementing public policy indicate interrelated relations.

Between the principal and the agent have a common interest in providing a large output value, but the agent will only try to meet the compatibility of incentives through principle. Nothing prevents the agent to demand a large remuneration to pretend with high effort, namely to be involved in the plunder of opportunism.

When the government decides to provide a set of public services, they must rely on a set of agents. The classic public administration model is described through a series of bureaus with specific functions, gathering expertise over time.

All actors in the implementation of village funds must have relationships and networks between actors, as agency theory views harmonious relations between actors implementing village fund policies so that it is expected that moral hazard and adverse selection will not occur which results in the blurring of the goals set. 
Asymmetric information is the forerunner that will cause moral hazard and adverse selection. Between the central government and village, the government must be transparent in managing information related to the whole related to the village. Village governments that must be transparent in managing village funds as well as the central government must truly play a control function through escorting with the community, village assistants, non-governmental organizations or, other relevant parties for the implementation of the village fund policy.

Asymmetric information that occurs in the process of implementing village funds can be identified in two (2) cases out of four (4) matters relating to differences in objectives between principal and agent. In the implementation of village fund implementation only identified different material information management links, related to differences in objectives between principal and agent. If material information is based on the principal's objective, then the information on the relationship of incompatibility such as the inaccurate targeting planned by the agent, in which the control of information is fully controlled by the principal. Whereas if material information is based on the agent's goals, then a conflicting situation will occur, where information is widely controlled by the agent.

\section{Research Method}

This study used qualitative approach using narrative study. Data collected from in-depth interviews with key informants representing stakeholders from government and community. Data were analysed using thematic analysis.

\section{Results}

In discussing the results of this study, the researchers discussed the principal agent in the implementation of the village fund by elaborating the explanation of the research results which were divided into three categories. First, the principal agent in the village fund planning stage. Second, the principal-agent is in the village fund implementation stage. Third, the principal agent in the village fund reporting phase.

\subsection{Principal-Agent in the Village fund Planning Phase in Linggo Village, Kejayan District}

In general, based on the facts on the ground that in the planning stage of the village fund in Linggo village, the District of Kejayan has been running, but there are still many weaknesses that are found starting from communication between actors that have not been maximized or even socialization related to village funds is very minimal carried out by the village government to the community, also the government apparatus resource at the beginning of the year of implementing the village fund program still requires adaptation to existing laws and regulations. So that the purpose of village funds has not yet been reached massively.

All actors in the implementation of village funds must have relationships and networks between actors, as agency theory views harmonious relations between actors implementing village fund policies so that it is expected that moral hazard and adverse selection will not occur which results in the blurring of the goals set.
Asymmetric information is the forerunner that will cause moral hazard and adverse selection. Between the central government and village, the government must be transparent in managing information related to the whole related to the village. Village governments that must be transparent in managing village funds as well as the central government must truly play a control function through escorting with the community, village assistants, non-governmental organizations, or other relevant parties for the implementation of the village fund policy.

Asymmetric information occurs if one or more parties have better information about the quality of a product or service that is exchanged compared to another party so that there is no balanced process of communication and information exchange between the perpetrators of the partnership. Asymmetric information does not mean that information is not owned, but sometimes the information cannot be obtained and is high cost until the exchange occurs, or sometimes it is obtained but it is too late. The emergence of asymmetric information and the existence of personal interests that are not always the same between the principal and the agent, affect the actions taken by the agent.

In the implementation of the Village fund in Linggo Village, Kejayan District, in line with Asymmetric Information, the village head as an agent has full control of the information on village development needs. The village, this information is sometimes a strength for the village government agent for the interests of groups and political interests. So that the regional government as an extension of the principal does not know anything about the needs of the community for certain.

Asymmetric information occurs if one or more parties have better information about the quality of a product or service that is exchanged compared to another party so that there is no balanced process of communication and information exchange between the perpetrators of the partnership. Asymmetric information does not mean that information is not owned, but sometimes the information cannot be obtained and is high cost until the exchange occurs, or sometimes it is obtained but it is too late. The emergence of asymmetric information and the existence of personal interests that are not always the same between the principal and the agent, affect the actions taken by the agent.

In the implementation of the Village fund in Linggo village, Kejayan District, in line with asymmetric Information, the Village Head as an Agent has full control of the information on village development needs. The village, this information is sometimes a strength for the village government agent for the interests of groups and political interests. So that the regional government as an extension of the principal does not know anything about the needs of the community for certain.

The findings in the field related to the preparation of priority programs, the village government agency has full control in determining the distribution of the village budget, as happened in the construction of paved roads for the hamlet, the priority scale is the hamlet, which is the basis for supporting the selection of the village head. 
Principal agents compete under perfect information that will resemble a referendum democracy or representative regime with an imperial mandate. In the two-party system in the Downs model, principals will choose the agents they want, they pay directly and accept the policies they like. Without rent, opportunism will not work. Also, one can assume that the politicians in the game are driven by vocation, as Max Weber's model of the ideal politician's agent.

In the case of the implementation of village funds, agency theory if synergized with the public policy can be seen in the process of implementing public policies, in this case, it can be seen from three perspectives: 1) the link between the principal and the agent, 2) the relationship between the principal and the community, 3 ) the relationship agent with the community.

The linkage that occurs as referred to above is how the communication occurs between the actors both to the principal, agents, and the community as the object of the policy. Principals and agents in the process of implementing public policy indicate interrelated relations.

Reaffirming the linkage referred to above is how the relationship of the central government as the principal to be more able to monitor agents, in this case, the village government in terms of managing village funds to be used for the ultimate goal of progress and independence of the village, besides that the principal is also very closely related to the community as well actors in the implementation of village funds, between the principal and the community are expected to have a harmonious relationship in guarding village funds so that the planned objectives can be achieved according to the specified targets. furthermore, the relationship between the village government as an agent and the community is no less important, both of them are also actors in the implementation of the closest village funds.

Between the principal and the agent have a common interest in providing a large output value, but the agent will only try hard when the compatibility of incentives is met through the principle. Nothing prevents agents to demand a large remuneration for pretending high efforts, namely to engage in the plunder of opportunism.

When the government decides to provide a set of public services, they must rely on a set of agents. The classic public administration model is described through a series of bureaus with specific functions, gathering expertise over time.

All actors in the implementation of village funds must have relationships and networks between actors, as agency theory views harmonious relations between actors implementing village fund policies so that it is expected that moral hazard and adverse selection will not occur which results in the blurring of the goals set.

Based on the results of theoretical and normative elaboration, as well as the reality in the field with the incompatible information available, the village government can make the village fund as a material prioritizing the funding of their group's political preferences over the interests of the actual village community.
4.2. Principal-Agent in the Implementation Phase of Village funds in Linggo Village, Kejayan District

In the process of implementing the village fund in Linggo village, Kejayan District, Pasuruan Regency, this has already been carried out. Implementation will be effective if the measures and objectives of the policy are understood by the individuals responsible for achieving the policy objectives. Communication in organizations is a very complex and complicated process. Someone can hold it for certain purposes or disseminate it. Besides that, different sources of information will also give birth to different interpretations.

Implementation of village funds in Linggo Village, Kejayan Subdistrict, Pasuruan Regency, there are many policies that the community does not choose but the community is shown a policy. For example, in the implementation of the community village fund activities, the implementation team has shown them. What should be done by the community is that the implementation team of the activity is then determined by the village head.

The reality in the implementation indicators of success in the field, then in the implementation phase of the Village fund program in the Linggo Village District of Kejayan has been running, but there are still many weaknesses found starting from communication between actors that have not been maximized or even socialization related to village funds is very minimal carried out by the village government to the community also, the government apparatus resource at the beginning of the year of implementing the village fund program still needs to be adapted to existing laws and regulations. Disposition and bureaucratic structure in the implementation of the program are still controlled by the village head and the village treasurer, so that the purpose of village funds has not been reached maximally.

The implementation of the village fund in the process of implementing the program in Linggo Village, Kejayan subdistrict related to asymmetric information, is the village head as an agent in full control of the information needs of village development, this is obtained from the village consultation that begins with the hamlet meeting so that all community needs in the village held by the village head, this information sometimes becomes a strength for the village government agent for the interests of groups and political interests. So that the regional government as an extension of the principal does not know anything about the real needs of the community.

Explanation of asymmetric the information above is in line with what is available in the field, because in reality, the field of OPD is related to the Village fund, in this case, the Village Community Empowerment Agency (DPMD), which explains that information asymmetry can occur but oversight is not maximized, so DPMD only focuses on fostering administratively adjust to the applicable laws and regulations.

On the other hand, there is the behavior of the implementing agent in the implementation phase of the village fund in Linggo village, Kejayan District concerningco Adverse Selection, the village head as an agent holding full control of the information needs of 
village development, in this case, illustrated in the selection pattern of the Activity Implementation Team (TPK) ) which tends to be behavior carried out by direct appointment.

Political preferences of village heads tend to be constraints in the implementation phase of the village fund program, a direct appointment system conducted by the village head shows that there is political interest being carried out, this relates to the spark plugs of the successful team in the selection of the village head, meaning the person appointed as tpk in the field is the closest people to village head it self.

The explanation above proves that in the appointment of the tpk conducted by the village head, the village did not go through a clear selection process, as long as the appointments had an impact on the implementation of the village fund program in the field. Even though the selection of the tpk was in accordance with the perception of the village head, the statement above illustrates that the person chosen was not competent, this could have an impact on development goals that are not in accordance with those set.

\subsection{Principal-Agent in the Village fund Reporting Phase in Linggo Village, Kejayan District}

Implementation of village funds in Linggo Village, Kejayan Subdistrict, Pasuruan Regency, there are many policies that the community does not choose but the community is given a policy. For example, in the accountability of the village fund activities the community participates in the meeting but only shows the report and must approve it.

In an agency relationship, the two parties (P-A) will try to maximize their utility with the principle of mutual benefit. However, because one party (especially an agent) possesses better information, there is a risk or possibility of opportunistic behavior by one party not to always act in the interests of the other party. This situation raises the emergence of incentives (temptations) for one or more actors (especially agents) to behave violently in order to maximize their own welfare and utility.

In relation to moral hazard behavior carried out in the implementation phase of the village fund program, when implementing the village fund program, it tends to be controlled by the village head, in general the implementation is transparent, but there are some things that are unknown to the citizens. Executing the program so that there may be negative behavior in the execution of the program.

At the reporting phase of village fund activity researchers found findings in the field that there was data showing that the village fund activity accountability report was only conducted in a meeting without showing results and there was no evaluation from the community. In the accountability report meetings the community fund activities are only present in the forum without having to issue an opinion or evaluation.

Based on theoretical and normative elaboration results, as well as the reality in the field of the four success indicators of the implementation stated above, the results of the study show that in implementation and villages in Linggo village, the subdistrict of Kejayan appears the domination of the village head as an agent who masters village information in relation to the use of village funds.

Asymmetric information is the forerunner that will cause moral hazard and adverse selection. Between the central government and village government must be transparent in managing information related to the whole related to the village. Village governments that must be transparent in managing village funds as well as the central government must truly play a control function through escorting with the community, village assistants, non-governmental organizations or other relevant parties for the implementation of the village fund policy. Asymmetric information that occurs in the process of implementing village funds can be identified in two (2) cases out of four (4) matters relating to differences in objectives between principal and agent.

In the case of the implementation of village funds, agency theory if synergized with public policy can be seen in the process of implementing public policies, in this case it can be seen from three perspectives: 1) the link between the principal and the agent, 2) the relationship between the principal and the community, 3 ) the relationship agent with the community. All actors in the implementation of village funds must have relationships and networks between actors, as agency theory views harmonious relations between actors implementing village fund policies, so that it is expected that moral hazard and adverse selection will not occur which results in the blurring of the goals set.

The simplest principal-agent illustration that is analyzing the interaction between the main risk and one risk unit to avoid the agent, where in the context of the implementation of the village fund according to the contract (pmk on the use of village fund finance) is clearly illustrated if the village government makes a mistake then the criminal threat as mentioned in the contract. In addition, joint supervision is needed in guarding the village fund both from the community element, and the element that has the authority.

\section{Discussion and conclusion}

In the implementation of the village fund in Linggo village, Kejayan District, in line with the Asymmetry Inforation, the village head as an agent has full control of the information on village development needs, this is obtained from the village consultation that begins with the hamlet meeting, so that all community needs in the village are held by the Kepalak Village, this information is sometimes a strength for the village government agent for the interests of groups and political interests. So that the regional government as an extension of the principal does not know anything about the needs of the community for certain. The findings in the field relate to the preparation of priority programs, the village government agency has full control in determining the distribution of the village budget, as happened in the construction of paving roads for the hamlet, the priority scale is the hamlet, which is the basis for supporting the selection of the village head.

In the context of the implementation of village fund policies in Desa Linggi, the Kejayan District, adverse selection can occur in the selection of the TPK, where the village head can just as long as point in determining 
the TPK, in this case there may be an interest of the village head in the implementation of the village fund Program. In conclusion, in the field of the village government, the vVillage fund can be used as a material to prioritize funding of their group's political preferences over the interests of village communities by playing the role of appointing TPKs for their political purposes.

All actors in the implementation of village funds must have relationships and networks between actors, as agency theory views harmonious relations between actors implementing village fund policies, so that it is expected that moral hazard and adverse selection will not occur which results in the blurring of the goals set. in conclusion, the incompatible information available, the village government can make the village fund as a material prioritizing the funding of their group's political preferences over the interests of the actual village community.

\section{References}

Aminullah, A. \& Aslikha. (2019). Citizen's Participation Level Analysis Dalam Pengelolaan Dana Desa di Desa Sukodermo Kecamatan Purwosari. SKETSA BISNIS, 6 (2), 77-86.

Kharisma, A. \& Supranoto, S. (2013). Implementasi Kebijakan Pemanfaatan Alokasi Dana Desa, Jurnal Ilmu Administrasi Negara, 12(2) 94-103

Miles, M.B., Hubberman, M. \& Saldana, J. (2014). Qualitative Data Analysis: A Methods Sourcebook. Sage Publications.

Smith B, \& Larimer C. (2009). The Public policy Theory Primer. West view Press.

Stanford, J. \& Moulton, M. (2014). Effective Implementation in Practice Integrating Public Policy and Management. Jossey-Bass A Wiley Brand.

Wijaya, A. F. \& Oscar, R.D. (2014). Manajemen Publik teori dan Praktik. UB Press. 